\title{
The 1968 Presidential Elections
}

\author{
by H. G. NICHOLAS
}

New College, Oxford

The electoral events of 1968 constitute a classical case of the vanity of political prediction. In 1964, in the wake of Mr Johnson's crowning mercy of November, political scientists were affirming the end of the Republican Party; the most that was to be looked for in the future was a one-and-a-half party system. In 1962 it was universally agreed amongst the politically sophisticated that Mr Nixon, by losing the California governor's race and, worse still, by publicly displaying his wounds and his chagrin, had wrecked all chances of a presidential nomination. In 1968, even after the New Hampshire primary, it was the conventional wisdom that Senator McCarthy's was, for all its gallantry, a children's crusade, of no serious significance for the course of American politics. Dis aliter visum. The twoparty system fully reasserted itself, even in a three-party year; Mr Nixon easily won the nomination and, by a hair's breadth, the presidency; finally, Senator McCarthy, despite his failure to win either, decisively affected the course of American policy in Vietnam, was probably responsible in large degree for Mr Johnson's abdication and may, by his own autumnal aloofness, have tipped the electoral balance from Humphrey to Nixon.

If the prophets were refuted, the fearful were also in large measure confounded. I 968 was, by any standards, a year of shocks and strains and troubles, but while recalling such events as the assassinations and riots, it is also important to remember what did not happen-the dire forebodings that went unrealized of 'the long hot summer' which was to turn every city into a battleground and the apprehensions that by the action of either side or both the fury of Vietnam would intensify and war spread. What happened in the violent arenas of Detroit, Cleveland and Saigon was enough to provide a permanently fresh orchestration to the election's major themes, but it is significant that it was the comparatively bloodless but visually more arresting events at Chicago that came nearest to diverting the various political performers from their pre-selected roles. The electoral process itself, despite the irruption of a de facto racist candidate, was virtually free of any violent incidents, either during the campaign or at the polls. Although American society, at almost every point, was feverish and 
disordered, the nation went through its democratic rituals with a degree of calm and tolerance that most universities, in the autumn of 1968 , would have given a good deal to reproduce in the management of their purely academic affairs. Much of the explanation for this lies outside the course of the election itself, e.g. in Mr Johnson's early decision to remove himself from the race, and as such is not germane to our inquiry. But what may be called the 'sedative' role of the election was also important; the election both benefited from and contributed to the somewhat calmer atmosphere which developed across the nation as 1968 wore on.

The campaigns of both major candidates took their inception, of course, from their nominating conventions. The conventions themselves are beyond the scope of this article, but they both symbolized and determined much of what each candidate did or was trying to do in the months that followed. The object of the Republicans at Miami was to re-forge the unity which had been the casualty of Mr Goldwater's adventure in 1964 . From this the nomination of $\mathrm{Mr}$ Nixon, as the candidate who divided the party least, was a logical, indeed inescapable, corollary. His own campaign for the nomination, quietly developed out of years of service to the party's candidates in state and congressional contests, reached an impressive but still almost deliberately unflamboyant climax at Miami. He won decisively enough to give him all-well, almost all-the freedom any candidate could ask for, and in the process he aroused the minimal rancour on the part of his defeated rivals-minimal, that is, compatible with the peculiar revulsion-attraction syndrome which appears an invariable concomitant of Mr Nixon's personality. As Mr Nixon himself described it after his nomination, 'The beauty of our contest this year was that we won the nomination in a way designed to win the election.' If complete Republican unity was still to seek after Miami it was because the gap between Left and Right, between the Eastern Establishment Liberals and the Western Reaganites and relics of Goldwaterism, was too broad for any politician or platform entirely to span. How broad it was became evident with the nominee's first official act-his selection of his running mate. That it should have to be his first act was unfortunate and possibly misleading in its symbolism, since it emphasized what was possibly the only respect in which the terms of Mr Nixon's own nomination left him less than fully free, his apparent dependence on Southern conservatism. Whatever the exact explanation of Governor Agnew's selection, it provided, in varying degrees, a provocation and an excuse for Republicans to cold-shoulder their candidate. The fact remains, however, that $\mathrm{Mr}$ Nixon went to great lengths, all the rest of the way from Miami to 5 November, to avoid any other action which might erode the party's solidarity a degree further. 
The violence which attended the Democratic Party's convention at Chicago almost over-shadowed, in its impact, the business of the convention itself. It had the effect, almost certainly misleading, of making $\mathrm{Mr}$ Humphrey's nomination appear attributable to Mayor Daley of Chicago. It certainly prevented any public appreciation of the various reformsmostly procedural, but every American conservative knows the value of the procedural-effected at the convention in the structure and functioning of the Democratic Party, such as the abolition of the unit rule. ${ }^{1}$ The impression went forth to watching millions that Hubert Humphrey's candidacy had been conceived in the corruption of machine politics and born in the violence of municipal storm-troopers. Mr Humphrey himself, at least as much victim as beneficiary of Mayor Daley's political midwifery, could effectively neither disavow nor defend the conduct of the Chicago authorities. This alone made impossible the building of that common front with the McCarthyites which his position as $\mathrm{Mr}$ Johnson's heir-apparent in any case made extremely difficult. Like some sort of miniature Vietnam in the living-room, the spectre of Chicago never ceased to haunt the Vice-President's campaign.

The long and stubborn refusal of Senator McCarthy to come to terms with 'the lesser evil' was, and will long continue to be, the object of severe criticism amongst those who saw the contest for the White House as the crucial issue in the politics of 1968 . But, of course, the distinctive character of the Senator's crusade lay in the fact that although it utilized the machinery of the presidential race its goal was not the capture of the Presidency but the transformation of American policy. This remained true even if, or when, surprising successes at the polls encouraged a hope that the White House itself might be within his grasp. From this point of view the familiar arguments of American 'pragmatic' or 'realistic' politics made little sense and the Senator's three conditions of support, laid down on 8 October, were far from excessive; they were a new government in South Vietnam, a drastic revision of U.S. conscription procedures and democratic reforms in the party. But in fact Mr Humphrey's Salt Lake City broadcast of 3o September, in which he undertook to stop the bombing of North Vietnam if Hanoi gave some sign of being willing to begin serious peace talks, represented the only movement in his position on any one of the areas specified by Senator McCarthy. Thus in fact as October ran out and polling day approached it was the Senator who made the unifying move when, on the 29th, he delivered his low-key endorsement of Mr Humphrey's candidature in terms which emphasized its anti-Nixon motivation. By then, of course, President Johnson's 3 I October announcement of the American bombing halt was known to be impending.

1 For which, however, $\mathrm{Mr}$ Humphrey himself did not vote. 
The leader of a crusade is, of course, no more free than any other kind of political leader from the laws which regulate his relations with his followers. Even if ideological revulsion had been lacking, it was not in Senator McCarthy's power to swing the rank and file of his movement into step behind Mr Humphrey's candidacy and close ranks immediately after Chicago. This was evidenced, clearly enough, by the refusal of the unofficial McCarthyite organization in New York State, the Coalition for an Independent Candidacy, to remove his name from the ballot even at the candidate's own request, until forced to do so by court action. Thus it is probable that any endorsement of Humphrey in more ringing terms or anything which antedated President Johnson's conversion to the idea of a bombing pause would have been self-defeating.

All this might imply that the presidential contest was dominated by the issue of Vietnam. At a fundamental level this was indeed so. It was the ground bass to everyone's thinking, candidates' and voters'; it set the limits to what could be said and done; it was the great incalculable, the factor which no one, not even the President, could control, the source from which some unpredictable development could suddenly throw the best laid plans into disarray. But in fact no such unpredictable development occurred (the bombing pause was certainly not one) and there was comparatively little exploitation of the Vietnam issue in the exchanges between the candidates.

The basic reason for this lay not with the candidates themselves, but with the curious way in which, to borrow the clumsy strategic metaphors of the period, a 'psychological de-escalation' of the Vietnam war had already developed in the American public mind. The history of the phenomenon is hardly germane here, but it is obviously related to the sobering jolt of the Tet offensive in 1967 and, still more, to Mr Johnson's spring decision both to step down himself and to scale down the American commitment. Although the nominating processes of the two parties failed to offer the electorate an opportunity to record a clear vote on the war issue and although from the viewpoint of the war's opponents there was little to choose between Nixon and Humphrey, nonetheless by the autumn of 1968 the Vietnam issue had in large measure been de-fused. There was a pervasive sense that the war was on the way out, that the problem before the country was no longer that of choosing between battling on to victory and extricating itself at all costs. ${ }^{1}$ There were no longer many votes to be won by posing as a hawk; the new role was that of the moderate or responsible dove. Consequently the only arguments between the candidates were really over the proportion in which responsibility and dove-ishness should be blended.

1 A landmark here is undoubtedly Mr McGeorge Bundy's speech of ro October. 
Thus when Mr Humphrey was critical of South Vietnam exercising a veto over any American decision to halt the bombing, Mr Nixon commented that such loose talk would only confuse the impending negotiations at Paris. It was out of such tactical trivia that the candidates tried to score off each other; they were denied any larger field of argument and yet they knew that public anxiety, amounting to impatience, for an end to the odious conflict demanded evidence from them of their concern and competence.

What then were the issues of the campaign? The question can never be an easy one to answer for a country with the size and diversity of a continent and for a contest which extends itself from August to November. In 1968 it was particularly difficult because for different reasons each candidate had his own interest in obfuscating issues rather than in clarifying them. $\mathrm{Mr}$ Nixon, having with infinite care reassembled as wide a Republican coalition as he could, was more worried about alienating any of his supporters than hopeful about attracting any recruits. Mr Humphrey, unable to disembarrass himself of the Johnson legacy (it was, after all, also his own), yet anxious to appear as a candidate in his own right, found a solution in any case attractive to his temperament in avoiding specifics wherever possible and dealing in large, rhetorical generalities. ${ }^{1}$ Besides this in most areas the normal weights and balances of American electoral politics were operative, by which a Republican candidate leans slightly to the left of his party's centre and a Democrat to the right of his. This meant that very often there was a good deal of overlap. This was obviously so on Vietnam, on EastWest relations in general, and on most aspects of defence policy. The nearest to a clear difference in the foreign policy field came on the issue of arms control, where Mr Nixon's insistence on delaying the ratification of the Nuclear Proliferation Treaty lent colour to the assumption that he lacked interest in an American-Soviet armaments agreement. Where foreign economic policy was concerned there was little electoral interest or debate, though there was reason to believe that the Republicans ran true to form in being more receptive to the pleas of the protectionists and more willing to give American investment capital a free hand abroad.

In fact, however, the domestic issues outranged, in variety and intensity, all the foreign ones, the Vietnam war alone excepted. Here Humphrey, the domestic reformer, felt on safest ground. Here equally Nixon, voicing the cumulative grievances of the citizen against his government, felt he had most to gain. But Mr Humphrey had little specific to offer, except more of

1 Cf. the difficulties in which Mr Humphrey was involved when he attempted a modest opening to the left by hinting that as the South Vietnamese undertook more of the burden of the fighting next year, so more Americans might be able to return home. Scarcely was the ink dry on the reports of his speech than the President volunteered the pointed snub, 'No man can predict the day when our men can come home.' 
the same-prosperity continued, even if combined with (some) inflation, the 'Great Society' programmes continued and improved, civil rights defended and extended. In criticism Mr Nixon was able to be more precise, with plenty of targets at which to aim, but apart from differences of emphasis-the evil of inflation, the tighter control over all welfare programmes-he was not rejecting either full employment or any of the established benefits won under Kennedy and Johnson. Challenging both candidates at every turn was the issue that could neither be evaded nor resolved, the crisis of the cities. Since no American leader or social philosopher has the answer to this, it is no criticism of the election to say that it threw little light on the problem either. Returning some federal tax revenues to cities and states, which both candidates favoured, or using tax incentives to get private business to interest itself in the problem, which was Mr Nixon's gimmick, were not the sort of answers which could dominate either the hustings or indeed the intractable issue itself. What most of the public wanted to hear about was the point at which the urban crisis became the problem of 'law and order' or, what was often its virtual synonym, the black ghetto. ${ }^{1}$ Here plenty was said, from statesmanlike 'position papers' to off-the-record and whistle-stop demagoguery, but the broad contrast of emphasis was clear enough-Mr Nixon's on the need to improve anticrime measures, detection and enforcement; Mr Humphrey's on the need to grapple with the causes of crime, in particular poverty and Negro backwardness. More than any other single issue, this served to distinguish the candidates from each other. It was in keeping with the centre of gravity of their constituencies-Mr Nixon's white, surburban and small-town middle class and Mr Humphrey's ethnically diverse, big-city working class. It chimed in with the personalities of the two men-Mr Nixon's calculating conservatism and Mr Humphrey's sentimental liberalism. This was important. Despite all the talk about rival policies, it was clearly observable, time and time again, how often, in public argument and (so far as one could assess it) private judgment, the issues of the campaign were seen as subordinate to the personalities. Indeed Mr Muskie, with that frankness which made him such an engaging (and often successful) campaigner, did not hesitate to admit as much to a New York Times interviewer ${ }^{2}$ in almost those very terms. And of course the candidates lent themselves to such a treatment-to their friends $\mathrm{Mr}$ Nixon was the perfect Horatio Alger of politics and $\mathrm{Mr}$ Humphrey the compassionate crusader; to their enemies

1 For the student of language there is a world of significance in the way in which this term has been more than half robbed of its derogatory, un-American connotation, and has become just a conveniently descriptive synonym for the central urban areas predominantly occupied by Negroes.

2 New York Times, 28 September 1968. 
they were 'Tricky Dick' and according to taste, left or right, L.B.J.'s puppet or a woolly-minded rhetorician. Not for the first time in American politics a clash of personalities covered up ambiguities and evasions over policy.

More, however, than ever before-or so at least it seemed-the form of the contest assisted in the down-grading of issues. Every American campaigner faced with the size and diversity of the country is always fighting a losing battle against time and space. He has to choose between trying to reach all of the people with a few very general thoughts and trying to reach some of the people with arguments specially tailored to each audience. The archetypal back-porch campaign represented the one option and the whistle-stop tour the other. TV and the aeroplane have now made it possible to indulge the illusion that both can be combined, that the candidate can speak to everybody the word he most wishes him to hear. It remains, however, an illusion. Even the most super-humanly energetic candidate, enjoying the best communication facilities and aided by the best party organization, can still not 'make his number' with every voter. What he is increasingly tempted to do is to blur his image and exhaust his energies in the effort to say at least something everywhere, to shake at least one symbolic hand in every township, to link himself for a few moments in group photograph or public platform with his party's henchmen in every county seat from Aroostook to San Diego. And in fact since what is technologically possible is not humanly possible, even the best planned campaign involves breakdown and wasted effort. Even $\mathrm{Mr}$ Nixon, at one point, found himself flying from Boston to Chicago to New York, some I,600 miles, simply to address a morning rally in a high school. Those who keep the logs for these formidable odysseys claim that during the campaign $\mathrm{Mr}$ Nixon covered over 50,000 and $\mathrm{Mr}$ Humphrey 90,000 miles. In reporting these incessant talking tours the press enjoyed every facility and expended every effort. Yet no clear picture emerged of what the candidates stood for or what their programmes were. Despite the tireless zeal of the political analysts, no clear strategy could be discerned in either camp and no development, in the sense of any debate or argument or interaction of opponent on opponent, took place in the whole campaign, except for occasional brief exchanges on marginal issues. This was no accident. Even if the candidates had wished it otherwise, which for the reasons given they did not, the sheer volume of diffuse oratory, most of it repetitive and stereotyped-'the' speechguaranteed that no peaks would emerge from these formless undulations, no mountain ranges from these dead, pock-marked lunar landscapes of cliché. By a predictable paradox the concentration on 'exposing' the candidate to the maximum number of voters resulted in no exposure at all; 
it is almost certainly true that by the end of the campaign the voters knew less about the candidates than they had at the beginning.

From this point of view the great pseudo-issue of the campaign, the argument about whether there should be a TV debate between the candidates and on what terms, was doubly unreal. It was unreal because obviously $\mathrm{Mr}$ Nixon had no intention of taking the risks which, after his experience in I960 with Kennedy, he believed, rightly or wrongly, to be inherent in any such encounter. But it was again unreal in that, from the public's point of view, what was needed was not necessarily the court-room drama of the two (or three) candidates arguing together in the same room, so much as some continuing dialogue throughout the campaign, with each candidate paying some heed to what the other was saying, instead of addressing himself exclusively and repetitively to his own supporters. It is this which the technically superlative communications facilities of the United States are totally ungeared to provide and which a diffuse and intermittently inoperative two-party system does nothing to encourage. This fault, apparent in all American elections, amounted in this one to a crippling disability. ${ }^{1}$

I have observed elsewhere that one of the distinctive features of the American electoral ritual is the opportunity it provides for maximum participation, not so much in the vote as in the race. ('Participatory politics', as urged and practised by the New Left in 1968 and earlier, is not quite this, though it is an interesting and recognisable derivative.) This consists, quite simply, in the facilities provided by an elastic-sided party system, by a loose (though also extremely intricate) set of electoral laws and a longstanding national addiction to forming organizations and joining them, to 'get into the act'. These elements were certainly all present in 1968 , even to the extent of an additional national party, Mr Wallace's Independents. Yet in the discharge of this traditional function the 1968 election must be judged a conspicuous failure. The outward forms were there-the classic hoop-la of parades, bands, dressed-up young women, songs, buttons, stickers. There was the usual rich proliferation of ancillary organizations designed to snare even the most politically detached group; my own favourite was the Rural Electric Americans for Humphrey and Muskie. But the vitality, enthusiasm and involvement they were designed to express

1 In fairness perhaps one ought also to add that this failure of the candidates to engage with each other contributed also to keeping the campaign temperature low and so to that calming of the public pulse which I have mentioned as one of the by-products of the election. There was very little trading of insults and no serious smear-spreading, with the single exception of Mr Nixon's characteristic acquittal of Mr Johnson from a charge which no one had publicly made, of having launched his efforts for peace in Vietnam in a 'cynical' attempt to aid Mr Humphrey. At the state and congressional levels, of course, there was some notably skilful in-fighting of a familiar kind. 
were not there. The alienation which was the hallmark of American society in 1968 was stamped on the presidential campaign too. Rallies were poorly attended. Even Mr Nixon's superlative organization, though it could turn out the crowds, was unable to hold them. As a seasoned observer expressed it:

'Before he is halfway through the 25 -minute performance, some of the youngsters in the balcony begin leaving. Embarrassingly, the trickle of defection becomes a steady stream until the gymnasium seats are one-quarter empty. It is not an organized walkout. They appear to have heard as much as they came to hear.' ${ }^{1}$

Mr Humphrey generally ended as badly without often beginning as well. In New York, in Herald Square at noon, he failed to fill his space. Even in Chicago Mayor Daley was unable (or unwilling) to man his line of route or fill his stadium for the last big rally of the campaign. In Houston even though the presence of the President and the appeal of the fabulous 'Astrodome' filled the vast hall, the audience began to melt away as soon as $\mathrm{Mr}$ Johnson had finished and a sizeable proportion had left by the time Mr Humphrey wound up. By contrast, it must be said, Mr Wallace drew large crowds and held them; often they were merely curious or vocally hostile, but they were never indifferent and they received at his hands the compliment of being treated like sentient, responsive beings, not mere receptacles for rhetorical overflow or the political equivalent of television commercials. $^{2}$

Needless to say this devitalization was reflected at the level of organization as well. The present decay of American party organization is not a phenomenon to be blamed on the politics or the candidates of 1968 . Under both Eisenhower and Kennedy the politics of charisma had been replacing the politics of loyalty to tradition and the machine, and Johnson, party man though he had been, had done nothing to arrest the process. But the selection by both parties of standard-bearers who incarnated the most lack-lustre elements in each weakened still further the appeal of party loyalty as such, without replacing it by any new personal evocativeness. To a remarkable degree both Nixon and Humphrey avoided their party's labels, and Republican and Democratic candidates up and down the country paid them the perverse compliment of doing the same. The great unifying force of party, which historically has bound in one mystical chain dog-catcher and President, was conspicuously lacking in I968. The disposition always latent in a Republican campaign to play down the party label,

1 David S. Broder in Washington Post, 27 October 1968.

2 That Mr Muskie should have leapt into overnight fame by inviting a heckler to share his platform, one of the oldest gags, one would have thought, in the business, is indicative simultaneously of the drab routine of the other three principal nominees and of the rarity of heckling in the demure ritual of American political meetings. 
since they are the minority party, spread this year to the Democrats as well. It was rare to see a campaign poster or sticker which gave the candidate's party identity and even wordy pieces of campaign literature would tuck such information inconspicuously away. In a sense this was, of course, another manifestation of the pervasive reluctance of the citizen to commit himselfthe avoidance of those badges of personal commitment, the button and the bumper sticker, so characteristically American. ${ }^{1}$ It was as if the candidate shunned the party and the voter shunned both. In return the party sometimes just 'sat on its hands' or withered to a skeleton; or else, as in Chicago, where it continued to have a certain strength and interests to conserve, it ignored the national ticket and concentrated on those offices which directly affected it, like that of the state Attorney-General. Organized labour, in many states a synonym for, in others a supplement to, the Democratic Party organization, was generally, in 1968 , in similar condition-often atrophied, often a political liability, often cool towards the national ticket. Often it was divided in its allegiance, or riddled with Wallace-ism. To any candidate less financially harassed than Humphrey, its aid would have been a doubtful asset; as it was, he was grateful for any money which state offices of COPE (Committee for Political Education) could place at his disposal. But for campaign workers, the indispensable human aids without which no election could be fought, the national tickets were overwhelmingly dependent on volunteers. ${ }^{2}$ This meant, in most cases, housewives and students. ${ }^{3}$ And here, in the organizing skills needed to recruit, train and employ such amateur talent, the Nixon professionalism enjoyed an overwhelming advantage.

As party declines, the new arts of public relations and professional campaign management take its place. It was a very old-fashioned campaign in 1968 that did not utilize the services of one of those professional campaign management firms, of whom Spencer-Roberts was the most celebrated pioneer, and whose growth has added so much to the costs and perhaps to the efficiency of political campaigning. To the costs because their basic tool is the opinion survey and the processing of its data and their basic technique lies in the exploitation of the possibilities of television. Surveys, computers and TV time eat up money. The claim is that they also save it, the surveys

1 By far the most conspicuous emblems of personal commitment were those faded flower symbols favoured by McCarthyite small car drivers which clung on to their owners' Volkswagens and Triumphs, like last roses of summer, long after the season of their relevance had passed.

2 Even Mr Nixon's organization was unable to spend sums comparable to those of the Kennedys on engaging hired help.

3 No one assessing the political significance of organized studentry should overlook the electoral value of such a unique reservoir of volunteer assistance in an age when the old-style precinct worker, living on the public payroll, is a vanishing figure. 
and computers by identifying targets, TV by reaching the maximum audience with the most flexible and powerful means of persuasion. Whether this is so or not, these new technicians, the soothsayers of contemporary politics, are in increasing demand. They serve no party; they work for the man who hires them. In general as the minority party and the richer party, Republicans used them more often, more intensively and more intelligently. But the Democrats used them whenever they could. Mr Humphrey entrusted the whole management of his television campaign to Joe Napolitan, a former public relations partner of Larry O'Brien, Humphrey's choice as Democratic National Committee Chairman. Mr Napolitan had limited resources but exploited them to the full; in particular by holding his fire until the last week of the campaign he secured, he claims, maximum return on his investment. Certainly Mr Humphrey's leap in the opinion polls in his last week was remarkable. Mr Nixon's campaign staff was studded with professional advertising and public relations men, from Frank Shakespeare, a vice-president of CBS, to $H$. R. Haldeman, a Los Angeles advertising executive, whose avowed task was that of 'programming the candidate'. With ample funds at their disposal, the only criticism they encountered was from those who felt that their very efficiency might, beyond a certain point, prove self-defeating.

Besides being the basic research instrument of the campaign manager's art, the opinion polls, as and when they appeared in the press, had undoubtedly their own effect upon the course of the campaign. Their alleged bandwagon effect was repeatedly and no doubt rightly denied, but it was generally agreed that they harmed the number two, in this case consistently Mr Humphrey, in his efforts to raise the large amounts of money needed for a presidential campaign. It is hard to bleed donors when you are demonstrably unlikely to win. Repeatedly Mr Humphrey found his campaign hampered, even stalled, by lack of funds, and scarce time and energy had often to be diverted from campaigning to fund-raising. $\mathrm{Mr}$ Wallace had less to complain of. It is possible, though unprovable, that he benefited from polls which gave him an inflated strength, so that his eventual vote was below expectation. The most remarkable feature of the polls was, of course the virtually undeviating level of Mr Nixon's performance, enjoying a percentage share that neither rose nor fell significantly from convention to election, thus making him the first victor who reached office without the aid of a rising tide. Knowledge that he lived, so to say, on a popularity plateau was of course a powerfully shaping force in his campaign; he was fortunate that the caution and negativism it inspired still left him with the infinitesimal margin that gave him victory. 
For the pollsters, the campaign bristled with difficulties. They suffered from the sickness of the society they studied, finding unusual difficulty in reaching those levels of opinion which in any case are hardest to measure, the urban poor. The Harris Survey found $63 \%$ of all big-city dwellers feeling 'more uneasy on the streets than a year ago', a phenomenon which made it harder to get good interviewers and harder for them to reach their samples. The Gallup Institute had to scrap a Harlem poll because of falsified data. When it came to projection the presence of a third candidate introduced large, novel hazards. Finally the voters' alienation from the political process made particularly difficult any calculation of turnout. Under these circumstances the polls did surprisingly well.

The result of the election, in immediate political terms, can best be described as 'minimal Nixon'. A $0.68 \%$ lead, 502,500 out of a total vote of 73.2 million, was only marginally better than the $0.1 \%$ or $118,55^{\circ}$ votes by which John Kennedy had beaten him in 1960 . His own share of the vote, $43.4 \%$, was the lowest since Woodrow Wilson's in I912. Translated into electoral college terms, of course, this came out as an indisputable majority -302 to Humphrey's I 9 I and Wallace's 45. But the weakness of Mr Nixon's drawing power was graphically illustrated by his failure to pull in his supporters in either House or Senate, making him the first president since Zachary Taylor to secure election without bringing in at least one house of Congress of his own party colour. This made it the more fortunate that Mr Wallace's attempt to upset the normal working of the system was a failure, the wide diffusion of his 9.9 million votes preventing his carrying more than five states of his own deep South and so being unable to throw the election into the House of Representatives. Thus once again, despite the hazards of the process, the American electoral system yielded a clear, if pianissimo, verdict and in this respect provided an appropriate conclusion to a hard-fought but unexciting campaign.

Any attempt to go behind the electoral totals and ask what the results signify in other than immediate terms runs into the difficulties inherent in all electoral analysis, however blithely and consistently they may be ignored by journalists, politicians and historians. The Wallace phenomenon is the easiest to dispose of. His $13.5 \%$ share of the national vote is less impressive than it looks. It was less than La Follette's Progressives polled in 1924 and, a perhaps more relevant comparison, a good deal less than the $21 \%$ which the Know-Nothings secured in 1856 . Moreover it was an overwhelmingly Southern protest; less than $45 \%$ of his popular vote came from other parts of the country. To say which of the other two contenders benefited from his intervention is very far from easy; the composition of the Wallace vote clearly varied from region to region and 
also from town to country and no confident generalization is possible. Of its long-term significance it is also hard to speak; the movement clearly does not lack funds and ended the campaign with more money in hand than it had at the beginning. Nor does it lack a continuing grievance so long as Negro aspirations arouse white prejudices or appear to deny white claims to enjoy the first-fruits of the political process. But Mr Wallace's decision to operate exclusively at the presidential level has left him with no organizational basis of support at the state or congressional levels while his unimpressive showing outside his five deep southern states in a year when so much was working in his favour makes him an unattractive prospect for 1972.

The Democrats emerged from their defeat in no way disgraced and with very little for remorse and recrimination to feed upon. In only two states, New Jersey and Illinois, could their failure be directly attributed to inefficiency or sabotage by disgruntled or corrupt local machines. Elsewhere their failures were not discreditable and in some states, such as Texas and Massachusetts, their performance was notably good; in Texas, by closing the ranks of feuding conservatives and liberals, the Wallace intrusion was turned to the Democrats' account; in Massachusetts Humphrey carried the state with almost twice the vote secured by Kennedy in 1960. But of course they would henceforward have to reckon without most of the South or the border states and their big-city vote might be viewed, like so much else in the big cities, as a wasting asset. It was also observable that although labour had rallied in the last stages of the campaign, the Gallup Poll's analysis suggests that fewer of the rank and file of labour voted Democratic than in any election since the New Deal-only $56 \%$. The Negro vote, of course, was $90 \%$ Democratic, but much of this strength was in the South, where new voters $(5 \mathrm{I} \%$ of non-whites voted in the region compared with $44 \%$ in 1964) swelled totals which, in any case, were exceeded by Republicans or Wallaceites. It would take an even greater increase in Negro participation in the South to outweigh the white votes which the Democrats have lost there.

The Republicans could take comfort from studying the other side of these pennies-particularly their new hold on the more affluent labour voter and the return of the mid-western farmer to his traditional allegiance. But they could not be other than unhappy at their total failure with the alienated Negro and their virtual exclusion from all the big cities-the two principal trouble areas, human and physical, of American politics. As the minority party their problem is always to win over Democrats and Independents; the Gallup Poll's analysis suggests that in 1968 they were less successful than usual in doing this and that it was the spoilage of Wallace rather than 
the seductiveness of Nixon that gave the Republicans the margin of victory.

Related to this is, of course, the low turnout of 1968 . Absolutely, more people voted in 1968 than ever before-some $73^{\circ} \cdot$ million-but as a percentage of a rapidly rising population their performance was much less impressive. Out of some 120 million Americans of voting age slightly less than $61 \%$ went to the polls. Even of those registered-and although registration, in most areas itself represents a positive investment of civic effort-only about $80 \%$ took the further step of casting a vote. In I 964 the turnout was $62 \%$, in $196064.5 \%$. When one considers that in 1968 , owing to new Negro registration and the stimulus of a three-way contest, the South sharply increased its turnout (e.g. Mississippi up to $50 \%$ from $33 \%$ in 1964 , Alabama up to $50 \%$ from $36 \%$ ), it will be seen that the performance over the rest of the country was even less impressive than the national average would suggest. In the light of these figures it is not fanciful to conclude that it was the Democrats who did not vote who gave the election to $\mathrm{Mr}$ Nixon. It is also reasonable to assume that the threat posed by $\mathrm{Mr}$ Wallace across the country prevented the turnout being even lower than it would have been had the Republican and Democratic candidates had to rely exclusively on the appeal of their own charismata.

This, however, is not the whole story of American voting behaviour in 1968. As if hoping to make up in quality what it lacked in quantity, the American electorate showed a degree of selectivity in its voting which was truly impressive. Although no index exists for measuring cross-voting the evidence suggests that there was more ticket-splitting in 1968 than in any previous presidential year. Frequently the candidates, particularly $\mathrm{Mr}$ Nixon, ran behind the field in Senate or Governorship races. Repeatedly voters picked and chose without much deference to party loyalty. New York State, no doubt, has always worn its Republicanism with a difference. Even so it was striking that the open advocacy of a Humphrey-for-President, Javits-for-Senator vote should have paid off so handsomely, Humphrey carrying the state by some 400,000 , Javits winning the largest majority of his career-over a million. At the same time the Republicans were recovering control of the State Assembly. At the opposite end of the country California provides an analogous example in reverse, with Nixon carrying the state by a $3 \%$ margin but with Max Rafferty, the conservative Republican who had his explicit endorsement for the Senate, losing to Alan Cranston by $5 \%$, while the Democrats, though gaining in congressional races, lost control of the state legislature for the first time in a decade. In Pennsylvania again the urban and industrial voters stayed loyal to give Humphrey almost a $4 \%$ lead, but they rejected the incumbent Democratic Senator, Joseph Clark, 
in favour of Richard Schweiker by over $5 \%$, while at the same time returning the state house to the Democrats. Such examples could be multiplied, but one, from the South, is too good to miss. In Arkansas George Wallace carried the state with $40 \%$ of the presidential vote, Senator Fulbright was re-elected with $60 \%$, Governor Rockefeller held on by a narrow margin, and yet his Lieut-Governor lost to a crypto-Wallace ostensibly-Democratic challenger. From these and other widespread anomalies it was not possible to construct any national pattern of political attitudes. They did, however, powerfully confirm the detachment of voter from party referred to earlier and, as such, raise questions about the difficulties which the American polity will encounter in trying to provide stability and responsibility in a period of shifting allegiances. Fluidity might in retrospect seem the key word of 1968 , but it was a fluidity which, at least for those who chose to participate in the political process, seemed to imply a discriminating rather than a merely vacillating electorate. 